\title{
EN MEMORIA: FERNANDO ABRUÑA RODRÍGUEZ 1922-2007
}

\author{
Jessé Román-Toro y Rafael Montalvo-Zapata
}

J. Agric. Univ. P.R. 93(3-4):299-308 (2009)

Fernando Joaquín Abruña Rodríguez nació el 5 de julio de 1922 en Arecibo, Puerto Rico. Cursó estudios primarios y secundarios en el pueblo de Jayuya. Sus estudios universitarios comenzaron en el Colegio de Agricultura y Artes Mecánicas de Mayagüez, Universidad de Puerto Rico, donde obtuvo el grado de Bachiller en Agronomía, Magna Cum Laude, en 1945. En el año 1948 obtuvo su grado de Maestro en Ciencias del Suelo en la Universidad de Rutgers, Nueva Jersey.

Durante los años de 1945-1948 trabajó para el Servicio de Conservación de Suelos en Mayagüez, Puerto Rico. Más tarde y hasta su retiro ocupó el cargo de Científico de Suelos en el Servicio de Investigación Agrícola, Departamento de Agricultura Federal. Como científico de suelos fue el primero en cuantificar los efectos de diversas prácticas agrícolas y manejo de suelo sobre las tasas de erosión. Estudió detalladamente la edafología de los suelos agrícolas en la región central de Puerto Rico y el efecto de las propiedades químicas sobre el rendimiento y calidad de los cultivos de mayor importancia económica en Puerto Rico. Realizó vasta investigación de campo en suelos y lideró una secuencia de trabajos reconocidos a nivel mundial donde describió las características de los suelos ácidos y cuantificó el efecto de la acidez del suelo, siendo el pionero en los diversos estudios de la acidez en los suelos tropicales. Contribuyó a la descripción de las propiedades físicas, químicas y mineralógicas de los suelos de Puerto Rico. En términos de cultivos agrícolas estudió los efectos de la fertilización con nitrógeno, fósforo y potasio sobre la producción intensiva de café, plátanos, pastos, raíces y tubérculos y otros cultivos. Además, realizó estudios sobre el manejo de riego y otros factores nutricionales para la optimización de rendimiento en siembras de arroz en los llanos costeros del norte y sur de Puerto Rico. Muchos de sus estudios han servido de base para el desarrollo y establecimiento de las recomendaciones de fertilización en cultivos y de encalado en suelos ácidos.

Su contribución al conocimiento de las propiedades de los suelos y los factores limitantes sobre la producción agrícola de los cultivos de 
importancia económica en Puerto Rico son un legado permanente para las futuras generaciones de profesionales de la agricultura. Estos trabajos quedan plasmados en sus más de 50 publicaciones científicas como autor principal y sobre 60 como coautor, la mayoría de las cuales se mencionan más adelante.

Fue miembro de la Sociedad de Honor Gamma Sigma Delta. Recibió el gran Premio de Servicio Superior del Departamento de Agricultura Federal por sus logros sobresalientes al aumentar la productividad agrícola de suelos empinados de Puerto Rico, desarrollar sistemas de manejo intensivo de alta productividad agrícola en los trópicos húmedos y por su liderato y asesoría ejemplar en diversas agencias agrícolas en Puerto Rico y Latinoamérica. Se esmeró en proveer inspiración y dirección de las tesis de maestría y doctorado de estudiantes graduados en Puerto Rico, los Estados Unidos de Norteamérica y varios países de Latinoamérica.

Fue miembro del Colegio de Agrónomos de Puerto Rico, la Sociedad Puertorriqueña de Ciencias Agrícolas (antes Sociedad Americana de Ciencias Agrícolas), la Sociedad de Conservación de Suelos de América y Sociedad de Ciencias del Suelo de América. En estas últimas dos sociedades ocupó el cargo de Secretario. Además, fue el autor principal del capítulo "Los Suelos de Puerto Rico" del libro Geovisión de Puerto Rico: Aportaciones Recientes al Estudio de la Geografía, editado por María Teresa Blanco de Galiñanes de la Editorial Universitaria de la Universidad de Puerto Rico. En diversas ocasiones fue consultor de la Junta de Planificación de Puerto Rico en la preparación de documentos relacionados con el desarrollo agrícola de Puerto Rico no solamente en los llanos costeros sino también en la región montañosa. Se destacó, además, en labores administrativas como Subdirector de la Estación Experimental Agrícola y Decano Asociado del Colegio de Ciencias Agrícolas de la Universidad de Puerto Rico, Recinto Universitario de Mayagüez, dándole un enfoque práctico a la investigación agrícola y al reclutamiento de recién graduados prometedores e interesados en las ciencias del suelo y diversos efectos agronómicos.

El profesor Abruña Rodríguez también participó en innumerables conferencias técnicas y talleres. Fue Consultor de Suelos, Científico Visitante, Profesor Visitante y Director de Estudiantes Graduados en 14 países latinoamericanos y Puerto Rico.

Fernando Abruña Rodríguez falleció el 20 de diciembre de 2007. Le sobreviven su esposa María Minerva Charneco, sus tres hijos: Fernando Luis, Héctor Daniel y Rubén Enrique, y sus nietos. Siempre lo recordaremos como un gran compañero, amigo jovial y colaborador. Su laboriosidad, disciplina y lealtad a su trabajo fueron algunas de las virtudes que adornaron su vida. 


\section{PUBLICACIONES}

Bonnet, J. A., P. Tirado-Sulsona y F. Abruña, 1947. Effect of lime-phosphorus and green manure on sweet potatoes and corn grown in acid soils. J. Agric. Univ. P.R. 31(4):303-321.

Bonnet, J. A., F. Abruña y M. A. Lugo-López, 1950. Trash disposal and its relation to cane yield, soil and water losses. J. Agric. Univ. P.R. 35(3):286-293.

Bonnet, J. A., M. A. Lugo-López y F. Abruña, 1951. Cation exchange capacity of some tropical soils of Puerto Rico. J. Agric. Univ. P.R. 35(2):49-56.

Jeffries, C. D., J. A. Bonnet y F. Abruña, 1952. Mineral characteristics of some soils of Puerto Rico. Soil Sci. Soc. Am. Proc. 16(3):310-311.

Lugo-López, M.A., F. Abruña y J. Roldán, 1952. Evaluation of the lime requirements of tropical soils in terms of other soil characteristics. J. Agric. Univ. P.R. 36(2):155-160.

Abruña-Rodríguez, F. y R. M. Smith, 1953. Clay mineral types and related soil properties in Puerto Rico. Soil Sci. 75(6):411-420.

Jeffries, C. D., J. A. Bonnet y F. Abruña, 1953. The constituent minerals of some soils of Puerto Rico. J. Agric. Univ. P.R. 37(2):114-139.

Abruña, F. y J. Vicente, 1955. Refinement of a quantitative method for determining the lime requirements of soils. J. Agric. Univ. P.R. 39(1):41-45.

Abruña-Rodríguez, F. y J. Vicente-Chandler, 1955. Organic matter activity in some typical soils of Puerto Rico. J. Agric. Univ. P.R. 39(2):65-76.

Smith, R. M. y F. Abruña-Rodríguez, 1955. Soil and water conservation research in Puerto Rico-1938-1947. Est. Exp. Agric., Univ. P.R., Bol. 124. 51 pp.

Abruña, F. y J. Figarella, 1957. Some effects of calcium and phosphorus fertilization on the yield and composition of a tropical kudzu-grass pasture. J. Agric. Univ. P.R. 41(4):231-235.

Abruña-Rodríguez, F., S. Rodríguez y J. Vicente-Chandler, 1957. Estudios sobre el cultivo de café a pleno sol en Puerto Rico. Revista del Café 12(6):6-8.

Abruña-Rodríguez, F., R. W. Pearson y C. Elkins, 1958. Quantitative evaluation of soil reaction and base status changes resulting from field applications of residual acid nitrogen fertilizers. Soil Sci. Soc. Am. Proc. 22(6):539-542.

Abruña, F., J. Vicente-Chandler y S. Silva, 1959. The effect of different fertility levels on yields of intensively managed coffee in Puerto Rico. J. Agric. Univ. P.R. 43(3):141-146.

Vicente-Chandler, J., F. Abruña-Rodríguez y S. Silva, 1959. A guide to intensive coffee culture. USDA Production Research Report No. 31.51 pp.

Silva, S., F. Abruña y J. Vicente-Chandler, 1960. The effect of yields on picking efficiency in coffee production. J. Agric. Univ. P.R. 44(4):173-175. 


\section{ROMÁN-TORO \& MONTALVO-ZAPATA/ F. ABRUÑA-RODRÍGUEZ}

Abruña-Rodríguez, F., J. Vicente-Chandler y S. Silva, 1962. El cultivo intensivo de café a pleno sol en Puerto Rico. La Revista del Café.

Pearson, R. W., F. Abruña-Rodríguez y J. Vicente-Chandler, 1962. Effect of lime and nitrogen applications on downward movement of calcium and magnesium in two humid tropical soils of Puerto Rico. Soil Sci. 93(2):77-82.

Vicente-Chandler, J., R. W. Pearson, F. Abruña-Rodríguez y S. Silva, 1962. Potassium fertilization of intensively managed grasses under humid tropical conditions. Agron. J. 54(5):450-453.

Abruña, F. y J. Vicente-Chandler, 1963. Effects of six sources of nitrogen on yields, soil acidity and leaf composition of coffee. J. Agric. Univ. P.R. 47(1):4146.

Abruña-Rodríguez, F., 1963. Conservación y producción en la altura de Puerto Rico. Revista de Agricultura de Puerto Rico 50(2):125-131.

Abruña-Rodríguez, F., J. Vicente-Chandler y R. W. Pearson, 1964. Effects of liming on yields and composition of heavily fertilized grasses and on soil acidity, under humid tropical conditions. Soil Sci. Soc. Am. Proc. 28(5):657-661.

Caro-Costas, R., F. Abruña y J. Vicente-Chandler, 1964. Response to fertilization of strip-cultivated plantains growing on a steep Latosol in the humid mountain region of Puerto Rico. J. Agric. Univ. P.R. 48(4) 312-317.

Vicente-Chandler, J., R. Caro-Costas, R. W. Pearson, F. Abruña-Rodríguez, J. Figarella y S. Silva, 1964. The intensive management of tropical forages in Puerto Rico. Est. Exp. Agr. Univ. P.R., Bol 137. 152 pp.

Abruña, F., J. Vicente-Chandler, L. A. Becerra y R. Bosque-Lugo, 1965. Effects of liming and fertilization on yields and foliar composition of high-yielding sungrown coffee in Puerto Rico. J. Agric. Univ. P.R. 49(4):413-428.

Abruña, F., J. Vicente-Chandler, S. Silva y W. Gracia, 1965. Productivity of nine coffee varieties growing under intensive management in full sunlight and partial shade in the coffee region of Puerto Rico. J.Agric. Univ. P.R. 49(2):244-253.

Abruña, F., S. Silva y J. Vicente-Chandler, 1966. Effects of yields, shade, and varieties on size of coffee beans. J. Agric. Univ. P.R. 50(3):226-230.

Vicente-Chandler, J. y F. Abruña-Rodríguez, 1966. Management systems for steep, humid tropical lands. First Pan American Congress of Soil Conservation Proc.

Vicente-Chandler, J., F. Abruña y S. Silva, 1966. Effect of shade trees on yields of five crops in the humid mountain region of Puerto Rico. J. Agric. Univ. P.R. $50(3): 218-225$.

Lugo-López, M. A. y F. Abruña, 1967. Importancia del conocimiento de los suelos en la planificación agrícola. Revista de Agricultura de P.R. 54 (1-2):58-74.

Abruña-Rodríguez, F. y J. Vicente-Chandler, 1967. Sugarcane yields as related to acidity of a humid tropic Ultisol. Agron. J. 59:330-331. 
Abruña-Rodríguez, F., E. G. Boneta-García, J. Vicente-Chandler y S. Silva, 1967. Experiments on tanier production with conservation in Puerto Rico's mountain region. J. Agric. Univ. P.R. 51(2):167-175.

Vicente-Chandler, J., R. Caro-Costas, R. Pearson, F. Abruña-Rodríguez, J. Figarella y S. Silva, 1967. El manejo intensivo de forrajeras tropicales en Puerto Rico. Est. Exp. Agric. Univ. P.R., Bol. 202.

Abruña-Rodríguez, F., J. Juárez, R. Pérez-Escolar y J. Vicente-Chandler, 1968. Effect of soil acidity and liming on yields and composition of sugarcane growing on an Ultisol. J. Agric. Univ. P.R. 52(2):85-100.

Hernández-Medina, E., F. Abruña y R. Del Valle, 1968. Response to magnesium of intensively managed sun-grown coffee. J. Agric. Univ. P.R. 52(3):185-194.

Silva, S., F. Abruña y J. Vicente-Chandler, 1968. Effect of picking frequency on yields and quality of intensively managed coffee. J. Agric. Univ. P.R. 52(4):339342 .

Vicente-Chandler, J., F. Abruña-Rodríguez, R. Bosque-Lugo y S. Silva, 1968. Intensive coffee culture in Puerto Rico. Est. Exp. Agric. Univ. P.R., Bol. 211.

Vicente-Chandler, J., F. Abruña y S. Silva, 1968. A comparison of two methods of renovating intensively managed coffee trees by drastic pruning. J. Agric. Univ. P.R. 52(3):179-184.

Silva, S., J. Vicente-Chandler y F. Abruña, 1969. Field losses of coffee and improved harvesting methods for intensively managed plantations. J. Agric. Univ. P.R. 53(4):268-273.

Vicente-Chandler, J., E. Boneta, F. Abruña y J. Figarella, 1969. Effects of clean and strip cultivation, and of mulching with grass, coffee pulp, and black plastic on yields of intensively managed coffee in Puerto Rico. J. Agric. Univ. P.R. 53(2):124-131.

Vicente-Chandler, J., S. Silva y F. Abruña, 1969. A new low-cost method of harvesting coffee in high-yielding plantations. J. Agric. Univ. P.R. 53(4):259-267.

Caro-Costas, R., F. Abruña y J. Figarella, 1972. Effect of nitrogen rates, harvest interval, and cutting heights on yield and composition of Star grass in Puerto Rico. J. Agric. Univ. P.R. 56(3):267-279.

Caro-Costas, R., F. Abruña y J. Vicente-Chandler, 1972. Comparison of heavily fertilized Pangola and Star grass pastures in terms of beef production and carrying capacity in the humid mountain region of Puerto Rico. J. Agric. Univ. P.R. 56(2):104-109.

Caro-Costas, R., J. Vicente-Chandler y F. Abruña, 1972. Effect of four levels of concentrate feeding on milk production by Holstein cows grazing intensively managed tropical grass pastures. J. Agric. Univ. P.R. 56(2):97-103.

Caro-Costas, R., J. Vicente-Chandler y F. Abruña, 1972. Effect of four levels of fertilization on beef production and carrying capacity of Pangola grass pastures in the humid mountain region of Puerto Rico. J.Agric. Univ. P.R. 56(3):219-222. 
Figarella, J., F. Abruña y J. Vicente-Chandler, 1972. Effect of five nitrogen sources applied at four rates to Pangola grass sod under humid tropical conditions. J. Agric. Univ. P.R. 56(4):410-416.

Silva, S., J. Vicente-Chandler, F. Abruña y J. A. Rodríguez, 1972. Effect of season and plant spacing on yields of intensively managed soybeans under tropical conditions. J. Agric. Univ. P.R. 56(4):365-369.

Vicente-Chandler, J., S. Silva, F. Abruña y J. A. Rodríguez, 1972. Effect of two cutting heights, four harvest intervals, and five nitrogen rates on yields and composition of Congo grass under humid tropical conditions. J. Agric. Univ. P.R. 56(3):280-291.

Vicente-Chandler, J., S. Silva, J. Rodríguez y F. Abruña, 1972. Effects of two heights and three intervals of grazing on the productivity of a heavily fertilized Pangola grass pasture. J. Agric. Univ. P.R. 56(2):110-114.

Caro-Costas, R., F. Abruña-Rodríguez y J. Vicente-Chandler, 1973. Comparison of heavily fertilized Pangola grass and Stargrass pastures under humid tropical conditions. Agron. J. 65:132-133.

Lugo-López, M. A., L. J. Bartelli y F. Abruña-Rodríguez, 1973. An overview of the soils of Puerto Rico: Classification and physical chemical and mineralogical properties. Est. Exp. Agr. Univ. P.R., Pub. 79.

Abruña, F. y J. Lozano, 1974. Effect of season of the year on yields of 13 varieties of rice growing in the humid region of Puerto Rico. J. Agric. Univ. P.R. 58(1):11-17.

Abruña, F., R. Pérez-Escolar, J. Vicente-Chandler, J. Figarella y S. Silva, 1974. Response of green beans to acidity factors in six tropical soils. J. Agric. Univ. P.R. 58(1):44-58.

Abruña, F., R. Pérez-Escolar, J. Vicente-Chandler, R. W. Pearson y S. Silva, 1974. Response of corn to acidity factors in eight tropical soils. J. Agric. Univ. P.R. 58(1):59-77.

Vicente-Chandler, J., F. Abruña-Rodríguez, R. Caro-Costas, J. Figarella, S. Silva y R. W. Pearson, 1974. Intensive grassland management in the humid tropics of Puerto Rico. Est. Exp. Agric. Univ. P.R., Bol. 233.

Abruña-Rodríguez, F., R. W. Pearson y R. Pérez-Escolar, 1975. Lime response of corn and beans grown on typical Ultisols and Oxisols of Puerto Rico. Cap. 15:261-282. Soil Management in Tropical America, CIAT.

Ramírez, C. T., F. Abruña-Rodríguez, J. Lozano y J. Vicente-Chandler, 1975. Effect of fertilization on yields of three varieties of rice at two locations in Puerto Rico. J. Agric. Univ. P.R. 59(1):1-4.

Vicente-Chandler, J., F. Abruña-Rodríguez y R. González-Trabal, 1975. Perspectivas para la producción de arroz en Puerto Rico. Est. Exp. Agric. Univ. P.R. (Informe) 
Vicente-Chandler, J., F. Abruña-Rodríguez y J. Lozano, 1975. Técnicas señalan la experimentación y el potencial para la producción comercial de arroz en Puerto Rico. Revista del Café 37-44.

Vicente-Chandler, J., F. Abruña-Rodríguez y S. Silva, 1975. Aspectos económicos del cultivo intensivo de café recolectado con mallas durante cuatro años en una plantación comercial. Est. Exp. Agric. Univ. P.R. Pub. 95.

Abruña, F., J. Figarella y R. Caro-Costas, 1976. Urea recubierta de azufre suple nitrógeno a pastos el año entero. Est. Exp. Agric. Univ. P.R. Adelantos Científcos Núm. 59.

Abruña, F., J. Figarella y R. Caro-Costas, 1976. Efficiency of sulfur-coated urea and potassium chloride compounds applied to Star grass growing on an Ultisol under humid tropical conditions. J. Agric. Univ. P.R. 60(3):310-15.

Abruña, F. y J. Lozano, 1976. Dos variedades de arroz producen bien con poco riego. Est. Exp. Agric. Univ. P.R., Adelantos Científicos Núm. 61.

Abruña, F., J. Vicente-Chandler, J. Figarella y S. Silva, 1976. Potassium supplying power of the major Ultisols and Oxisols of Puerto Rico. J. Agric. Univ. P.R. $60(1): 45-60$.

Caro-Costas, R., F. Abruña y J. Vicente-Chandler, 1976. Effect of three levels of fertilization on the productivity of Stargrass pastures growing on a steep Ultisol in the humid mountain region of Puerto Rico. J. Agric. Univ. P.R. 60(2):172178.

Caro-Costas, R., J. Vicente-Chandler y F. Abruña, 1976. Comparison of heavily fertilized Congo, Star, and Pangola grass pastures in the humid mountain region of Puerto Rico. J. Agric. Univ. P.R. 60(2):179-185.

Lozano, J. y F. Abruña, 1976. Arroz de grano corto produce bien todo el año. Est. Exp. Agric. Univ. P.R., Adelantos Científicos Núm. 60.

Vicente-Chandler, J., F. Abruña y S. Silva, 1976. Resultados económicos del cultivo intenso de café recolectado con mallas en una plantación comercial. Revista del Café 13-16. Mayo.

Abruña, F. y J. Lozano, 1977. Productivity of 25 varieties of rice grown under conditions of limited moisture. J. Agric. Univ. P.R. 61(1):1-5.

Abruña, F., M. A. Lugo-López y R. Pérez-Escolar, 1977. Los Suelos de Puerto Rico. Parte III. Geovisión de Puerto Rico. Univ. P.R. 123-57.

Lozano, J. y F. Abruña, 1977. Effect of planting season on yields of eight shortgrain varieties of rice under irrigation. J. Agric. Univ. P.R. 61(1):6-10.

Pearson, R. W., R. Pérez-Escolar, F. Abruña, Z. F. Lund y E. J. Brenes, 1977. Comparative response of three crop species to liming several soils of the Southeastern United States and of Puerto Rico. J. Agric. Univ. P.R. 61(3):361-82. 
Vicente-Chandler, J., F. Abruña, J. Lozano, S. Silva, A. Rodríguez y C. T. Ramírez, 1977. Cultivo intensivo y perspectivas del arroz en Puerto Rico. Est. Exp. Agric. Univ. P.R. Bol. 250.

Abruña, F., J. Rodríguez, J. Badillo-Feliciano, S. Silva y J. Vicente-Chandler, 1978. Crop response to soil acidity factors in Ultisols and Oxisols in Puerto Rico - Soybeans. J. Agric. Univ. P.R. 62(1):90-112.

Abruña, F., 1979. Response of soybeans to liming on acid tropical soils. Proceedings of World Soybean Conference, Raleigh, N.C. March.

Abruña, F., J. Vicente-Chandler, J. Rodríguez, J. Badillo y S. Silva, 1979. Crop response to soil acidity factors in Ultisols and Oxisols in Puerto Rico-Sweet potato. J. Agric. Univ. P.R. 63(2):250-67.

Abruña, F., 1980. Potassium supplying power of the major upland Inceptisols of Puerto Rico. J. Agric. Univ. P.R. 64(1):9-28.

Abruña, F., 1980. Potassium fertilization in Puerto Rico. Proc. of the Fertilizer Technology Transfer Conf., Mayagüez, P.R. Diciembre.

Abruña, F. y R. Pérez-Escolar, 1980. Liming in Puerto Rico. Proc. of the Fertilizer Technology Transfer Conf., Mayagüez, P.R. Diciembre.

Abruña, F., J. Vicente-Chandler, H. Irizarry y S. Silva, 1980. Evapotranspiration by plantains and the effect of frequency of irrigation on yields. J. Agric. Univ. P.R. 64(2):204-210.

Abruña, F., N. Díaz y J. Vicente-Chandler, 1981. Studies on the management of a wild yam (Dioscorea alata) and a wild tanier (Xanthosoma sp.). J. Agric. Univ. P.R. 65(1):58-61.

Irizarry, H., F. Abruña, J. Rodríguez y N. Díaz, 1981. Nutrient uptake by intensively managed plantains as related to stage of growth at two locations. J. Agric. Univ. P.R. 65(4):331-345.

Lozano, J. M. y F. Abruña, 1981. Nitrogen rates in single and split applications and yield of flooded rice. J. Agric. Univ. P.R. 65(1):35-42.

Lugo-López, M. A. y F. Abruña, 1981. Significance of the presence of potassium bearing feldspars and micas in some soils of Puerto Rico. Est. Exp. Agric. Univ. P.R. Bol. 265.

Lugo-López, M. A., F. Abruña y R. Pérez-Escolar, 1981. The role of crop and industrial residues on erosion control, properties and productivity of some tropical soils of Puerto Rico. Est. Exp. Agric. Univ. P.R. Bol. 266.

Rodríguez-García, J., F. Abruña y N. Díaz, 1981. Effect of artificial shade levels and of intercropping with plantains on tanier yields. J. Agric. Univ. P.R. 65(4):326-330.

Abruña, F., J. Vicente-Chandler, E. Rivera y J. Rodríguez, 1982. Effect of soil acidity factors on yield and foliar composition of tropical root crops. Soil Sci. Soc. Am. J. 46(5):1004-1007. 
Abruña, F., 1982. Response of rice to nitrogen fertilization in Puerto Rico. Presented at the Int. Workshop on Practical Applications of Azolla for Rice Production at Mayagüez, P.R. Noviembre.

Lozano, J. M. y F. Abruña, 1982. Season of the year on yields of seven mediumgrain varieties of rice. J. Agric. Univ. P.R. 66(3):188-93.

Lozano, J. M. y F. Abruña, 1982. Effect of planting methods and seeding rates on rice yields. J. Agric. Univ. P.R. 66(3):194-199.

Abruña, F., 1983. Potassium supplying capacity of six upland Mollisols from Puerto Rico. J. Agric. Univ. P.R. 67(4):394-406.

Abruña, F., J. A. Rodríguez-García y J. Badillo-Feliciano, 1983. Crop response to soil acidity factors in Ultisols and Oxisols in Puerto Rico, VII. Dry Beans. $J$. Agric. Univ. P.R. 67(4):429-437.

Abruña, F., J. Rodríguez y S. Silva, 1983. Crop response to soil acidity factors in Ultisols and Oxisols in Puerto Rico. VI. Grain sorghum. J. Agric. Univ. P.R. 67(1):28-38.

Abruña, F., J. Vicente-Chandler y J. A. Rodríguez-García, 1983. Crop response to soil acidity factors in Ultisols and Oxisols in Puerto Rico. VIII. Yams. J. Agric. Univ. P.R. 67(4):438-445.

Lozano, J., E. Rivera y F. Abruña, 1983. Effect of season of the year on yields of several varieties of dry beans growing in two ecological regions of Puerto Rico. J. Agric. Univ. P.R. 67(4):379-385.

Rodríguez-García, J., F. Abruña y H. Irizarry, 1983. Spraying for leaf spot and liming increase yam (Dioscorea alata L.) yield. J. Agric. Univ. P.R. 67(3):286292.

Silva, S., J. Vicente-Chandler y F. Abruña, 1983. Water management systems and rice yields under humid tropical conditions in Puerto Rico. J. Agric. Univ. P.R. 67(4):386-389.

Vicente-Chandler, J., F. Abruña, J. Badillo-Feliciano y J. A. Rodríguez-García, 1983. The effect of soil acidity factors on crop yields. IX. Taniers. J. Agric. Univ. P.R. 67(4):446-452.

Vicente-Chandler, J., R. Caro-Costas, F. Abruña y S. Silva, 1983. Producción y utilización intensiva de las forrajeras en Puerto Rico. Est. Exp. Agric., Univ. P.R., Bol. 271.

Abruña, F. y E. Rivera, 1984. Effects of soil acidity factors on yield and foliar composition of two rice varieties with supplementary overhead irrigation, $J$. Agric. Univ. P.R. 68(4):413-422.

Abruña, F., E. Rivera y J. A. Rodríguez-García, 1984. Crop response to soil acidity factors in Ultisols and Oxisols in Puerto Rico. X. Pigeon peas. J. Agric. Univ. P.R. 68(4):433-443. 


\section{ROMÁN-TORO \& MONTALVO-ZAPATA/ F. ABRUÑA-RODRÍGUEZ}

Vicente-Chandler, J., F. Abruña y J. Lozano, 1984. Molasses distillery slops supply nitrogen and potassium fertilizer to flooded rice. J. Agric. Univ. P.R. 68(4):395-403.

Rivera, E., F. Abruña y J. A. Rodríguez-García, 1985. Crop response to soil acidity factors in Ultisols and Oxisols in Puerto Rico. XI. Cassava. J. Agric. Univ. P.R. 69(2):145-151.

Rivera, E., J. Rodríguez y F. Abruña, 1985. Crop response to soil acidity factors in Ultisols and Oxisols in Puerto Rico. XII. Tomatoes. J. Agric. Univ. P.R. 69(3):357-365.

Rivera, E., J. Rodríguez y F. Abruña, 1985. Crop response to soil acidity factors in Ultisols and Oxisols in Puerto Rico. XIII. Cabbage. J. Agric. Univ. P.R. 69(3):367-376.

Rodríguez-García, J., E. Rivera y F. Abruña, 1985. Crop response to soil acidity factors in Ultisols and Oxisols in Puerto Rico. XIV. Plantains and bananas. $J$. Agric. Univ. P.R. 69(3):377-382.

Lozano, J., J. Vicente-Chandler y F. Abruña, 1986. Effect of straw disposal method and of nitrogen rates on rice yields and recovery of fertilizer nitrogen. J. Agric. Univ. P.R. 70(2):91-97.

Lugo-López, M. A., F. Abruña, J. Vicente-Chandler, H. Irizarry, J. Badillo, J. Rodríguez y E. Rivera, 1986. Comparative response to liming of various non-traditional export crops grown in Ultisols and Oxisols of the Caribbean. Proc. Caribbean Food Crops Society 22:254-260

Olmeda, R. F. y F. Abruña, 1986. Four nitrogen levels and three water management systems on rice yield and nitrogen recovery. J. Agric. Univ. P.R. 70(3):197205.

Abruña, F. y M. A. Lugo-López, 1987. Restoration of productivity in tropical eroded soils under appropriate management. J. Agric. Univ. P.R. 71 (1):13-22.

Abruña, F., 1987. Response of stargrass to $\mathrm{K}$ fertilization as affected by liming, $\mathrm{N}$ and $\mathrm{K}$ sources. J. Agric. Univ. P.R. 71(1):23-32.

Lugo-López, M. A. y F. Abruña, 1995. Magnitude of soil losses throughout the Caribbean. J. Agric. Univ. P.R. 79 (1-2):89-90. 